\title{
Evaluation of the zootechnical parameters of 'Poulet du Faso' fed with rations formulated by the design of experiments method
}

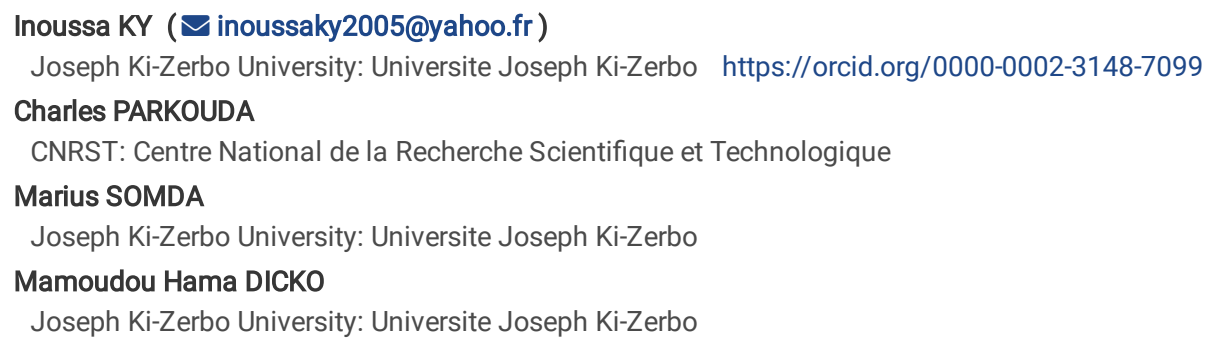

\section{Research Article}

Keywords: Formulation, experimental design, poultry feed, zootechnical parameters.

Posted Date: February 15th, 2022

DOI: https://doi.org/10.21203/rs.3.rs-1299307/v1

License: (9) (1) This work is licensed under a Creative Commons Attribution 4.0 International License. Read Full License 


\begin{abstract}
The aim of the study was to evaluate the effects of feed formulation using the design of experiments methodology on the zootechnical performance of the local hen in Burkina Faso. The experimental flock consisted of one hundred (100) 11-day-old chicks of the "Poulet du Faso" breed, randomly divided into ten lots of ten chicks. Ten feed rations resulting from the formulation by the experimental design method were prepared to feed the ten batches of poultry. Feed intake, live weight, average daily gain and feed efficiency were monitored weekly for 9 weeks. At the end of the study, the average daily food consumption varied from $112.30 \pm 50.79$ to $119.49 \pm 52.11 \mathrm{~g} / \mathrm{d}$, the average live weight of the subjects varied from $1089.53 \pm 0.07 \mathrm{~g}$ to $1660 \pm 0.12 \mathrm{~g}$. The average daily gain varied from $22.81 \pm 2.11 \mathrm{~g} / \mathrm{d}$ to $31.92 \pm 2.85 \mathrm{~g}$ and the consumption index varied from $3.92 \pm 1.92$ to $5.34 \pm 2.68$.
\end{abstract}

The dissemination of this information to poultry farmers could improve their production yields and the profitability of their activity.

\title{
1. Introduction
}

Livestock plays an important role in the economy of West African countries, contributing up to $44 \%$ of agricultural GDP. With more than 60 million head of bovines, 160 million small ruminants and 400 million poultry, the Sahel and West Africa are a livestock region par excellence (CEDEAO/OCDE/CSAO, 2008).

In Burkina Faso, as in most developing countries, economic and social development is based on improving the performance of the primary sector. Indeed, the primary sector, which includes agricultural activities in the broad sense (including livestock, fishing and forestry), employs about $86 \%$ of the active population. (Insd, 2008)

Livestock accounts for about 10 to 20 percent of the country's gross domestic product (GDP) and is the second largest contributor to agricultural value added, after cotton (FAO, 2018). Livestock products rank third in exports, after gold and cotton, with a contribution of 26\% (MRA, 2010).

With 44 million heads of poultry (FAO, 2019), the poultry industry provides livelihoods for approximately 1.6 million producers and households, particularly women in rural areas (Ayssiwede et al., 2013; FAO, 2019) and contributes about 6\% of agricultural GDP, (FAO, 2018). Poultry farming is dominated by the breeding of local poultry, which accounts for more than $98 \%$ of the national population (FAO, 2019). The local chicken, a source of income for the farmers (FAO, 2018), is used in many ritual sacrifices and religious ceremonies such as weddings and baptisms (Hofman 2000 ; Sonaiya and Swan 2004 ; Kondombo 2005). Notwithstanding these apparent strong contributions, local poultry productivity is low due to insufficient feed quality and quantity and poor husbandry conditions (FAO, 2019). Indeed, the availability of complete feeds for local poultry has not been a priority in poultry policies in recent years, leaving this breed to feed generally on household waste (Kondombo 2005 ; Pousga et al. 2005) or discarded cereal seeds. However, in poultry farming, feed, which is the main factor of productivity and economic profitability of the farmers, can represent $70 \%$ of variable production costs (Oladokun and Johnson, 2012 ).

Feed formulation consists in gathering several available raw materials, quantifying their incorporation rate and putting them together to form a homogeneous mixture in order to satisfy all the nutritional needs of the poultry in accordance with the production objectives (Saxena, 2012). Some poultry farmers use inefficient manual methods, others improvise approaches to solve poultry feed formulation problems (Oladokun and Johnson, 2012).

In view of these constraints, specialists have taken up and developed methods to formulate a food at a lower cost thanks to the development of computerassisted mathematical programming (Brah et al., 2016). Despite the importance of these methods, their application in the field of poultry feed formulation is far from sufficient due to the variability and quality of the raw materials. The development of rigorous mathematical approaches becomes a permanent quest in this field.

The objective of this study is to contribute to the improvement of feed formulations through the methodology of experiments, especially mixing designs, in order to improve the zootechnical performance of local poultry in Burkina Faso, commonly known as « Poulet du Faso »

\section{Materials And Methods}

\subsection{Study site}

The study was conducted on a farm in TOECE, (Latitude $11^{\circ} 49^{\prime} 46^{\prime \prime}$ North, Longitude: - $1^{\circ} 15^{\prime} 44^{\prime \prime}$ West), a rural commune located in the Centre-South region of Burkina Faso about $75 \mathrm{Km}$ from the capital Ouagadougou. The climate is of the Sudano-Sahelian type with a rainy season from May to October and a dry season from November to April. The dry season is dominated by cold and dry winds (harmattan) from December to February and hot and dry winds from March to April while the rainy season is dominated by the monsoon. The average annual rainfall is between 500 and $1200 \mathrm{~mm}$ (INSD, 2014)

\subsection{Animal material}

The animal material consisted of 100 unsexed 11-day-old chicks of the local breed "Poulet du Faso" obtained at the FADIMA farm located in Ouagadougou and transported to the "Expertise For Sens and Empowerment" farm where the study took place. An initial weight measurement of each chick was performed upon arrival at the farm.

\subsection{Experimental cage}

The chicks were divided into ten batches of ten and each batch was reared on wood chip litter in a $1.5 \mathrm{~m} 2$ experimental cage that had been previously disinfected. The cages were designed with wood and wire mesh. The bedding was changed every two weeks to minimize contamination.

\subsection{Formulation of feed rations}


The food rations were carried out by the method of the plans of experiments in particular the plan of mixture which is a technique allowing to better organize the tests to lead to better results (Goupy, 2006). Minitab version 8.1 was used for this purpose.

Thus, ten raw materials, chosen on the basis of their availability, their nutritional value and their cost, were retained as factors of the formulation plan. These are ground corn grain, ground cottonseed meal, ground soybean meal, wheat bran, rice bran, fish meal, oyster shell, dicalcium phosphate, salt and Concentrated Mineral Vitamin Azote (CMVA). The lower and upper limits of these factors were set by the method developed by John CORNELL (1941) while taking into account the recommended incorporation thresholds as described in the work of Ngom (2004). Table I shows the lower and upper limits of the various factors.

The formulation matrix was constructed according to the method of Henri SCHEFFE (1958) using the Simplex Lattice Design with a mesh size m=1. Thus, a matrix containing ten food formulas was automatically generated by the software. The approach consisted in varying the proportion of the constituents so that the sum is equal to one hundred (100). The top level of each factor was combined with the bottom level of the other nine (9) constituents. Table II represents the formulas of the experimental rations obtained by the mixing design method. These formulas have been coded from R1 to R10. The rations were prepared using a locally manufactured grinder-mixer according to the proportions of the different raw materials indicated in the formulation matrix. Two $500 \mathrm{~g}$ samples of each formulated ration were characterized by conventional laboratory methods to assess their biochemical composition (Table II). The cost of rations was estimated by summing the products of the prices of raw materials by their proportion in the ration (Table II).

\subsection{Conduct of experiments and collection of zootechnical data}

After the ten rations were obtained, each batch of ten chicks was fed with one ration for sixty (60) days or approximately nine (09) weeks, under the same conditions. The food was served twice a day, morning and evening, at 8am and 7pm as described in NDIAGNE's work (1996). The chickens were fed and watered ad libitum. The water in the troughs was changed three times during the day, in the morning and evening before the feed was distributed, and at $1: 00$ pm.

All subjects underwent the national medical prophylaxis protocol (MASA, 2013) against fowl plague, Gumboro disease, fowl pox, coccidiosis, helminth diseases and parasitic diseases.

For each experimental ration, the average value of food consumption and live weight were recorded. Daily weight gain (DWG) was deduced from the one-week weight gain by dividing it by seven. The consumption index $(\mathrm{Cl})$ was assessed as the ratio of daily food consumption to daily weight gain.

\subsection{Statistical analysis}

The mean values of the data were subjected to analysis of variance (ANOVA) with the software "XLSTAT version 7.5.2" at the significance level of 5\%.

\section{Results And Discussions}

\subsection{Results}

The mean values of daily food consumption of the subjects ranged from $112.30 \pm 50.79$ to $119.49 \pm 52.11 \mathrm{~g} / \mathrm{d}$ (Table III). Ration R9 had the highest consumption with a mean individual food consumption of $119.49 \pm 52.11 \mathrm{~g} / \mathrm{d}$. It is followed by the R4 ration $(118.78 \pm 51.77 \mathrm{~g} / \mathrm{d})$ and the R1 ration $(116.57 \pm 51.27 \mathrm{~g} / \mathrm{d})$. The R2 ration was the least consumed with $112.30 \pm 50.79 \mathrm{~g} / \mathrm{d}$ of average food consumption. Statistical analysis of variance of weekly consumption data showed a significant difference $(P<0.05)$ between the consumption of rations R7 and R8 with the other rations from the beginning of the experiment to the 3 rd week. This difference is well illustrated by the graphical representation of the evolution of consumption during the trial (Figure 1 ).

Le poids vif moyen des sujets à la fin de l'étude a varié de 1089,53 $\pm 0.07 \mathrm{~g}$ à $1660 \pm 0,12 \mathrm{~g}$ (Tableau IV). Subjects fed the R6 ration had the highest average live weight $(1660 \pm 0.12 \mathrm{~g})$. They are followed by subjects fed with the R10 ration $(1605 \pm 0.17 \mathrm{~g})$ and the R3 ration $(1601.51 \pm 0.24 \mathrm{~g})$. The subjects fed the R7 and R9 rations had the lowest average weights with $1089.53 \pm 0.07 \mathrm{~g}$ and $1170.05 \pm 0.12 \mathrm{~g}$ respectively. A statistical analysis $(P<0.05)$ of the live weight gains of the subjects shows a significant difference between the different rations. This difference is well illustrated by the graphical representation of the evolution of the growth of the subjects (Figure 2).

The R6 ration resulted in faster growth of the subjects, with an average daily gain of $31.92 \pm 2.85 \mathrm{~g} / \mathrm{d}$ (Table V). It is followed by the R3 ration ( $28.52 \pm 2.12 \mathrm{~g} / \mathrm{d}$ ) and the R2 ration $(27.07 \pm 2.44 \mathrm{~g} / \mathrm{d})$. The growth rate of the subjects fed with R7 and R9 rations was the lowest with $22.81 \pm 2.11 \mathrm{~g}$ and $23.39 \pm 2.46 \mathrm{~g} /$ respectively. Overall, we note a drop in growth rate with the age of the subjects (Figure 3 ).

Subjects fed R9 had the highest mean consumption index (5.34 \pm 2.68$)$ followed by those fed R7 (5.21 \pm 2.77$)$. Subjects fed the R6 ration had a lower

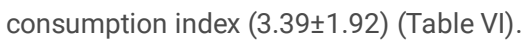

The cost of formulating rations varied from 203.40 to $238.98 \mathrm{FCFA} / \mathrm{kg}$ with an average value of $213.77 \mathrm{FCFA} / \mathrm{Kg}$ (Table II). Ration R8 is the most expensive (238.98 FCFA $/ \mathrm{kg}$, followed by R10 (234.23 FCFA $/ \mathrm{kg}$. The formulation cost of the R5 ration is the least expensive (203.4 FCFA/kg) followed by the R9 ration (205.29 FCFA/kg).

The formulation cost of the R5 ration is the least expensive (203.4 FCFA/kg) followed by the R9 ration (205.29 FCFA/kg)

\subsection{Discussions}

The mean individual feed intakes of the rations are well above the mean intakes $(49 \mathrm{~g} / \mathrm{d})$ and $(71.9 \pm 11.3 \mathrm{~g} / \mathrm{d})$ of the rations formulated respectively by Bayala et al., (2016) and Hien and Coulibaly (2017) on local poultry in Burkina Faso. However, the results of this study are well below the average

Page 3/11 
consumption $(923.50 \mathrm{gr} / \mathrm{dr})$ of the ration formulated by Crop et al., (Crop et al., 2014) for broiler chickens in Congo.

The difference in feed consumption of chickens could be related to the difference in cellulose content of the different rations formulated by the different authors. Indeed, Ngueba (2006) reported in his work, that when birds are fed ad libitum, a diet rich in cellulose causes a congestion of the crop. He indicated that the regulation of feed intake in chickens is related to the degree of filling and emptying capacity of the crop.

Moreover, between rations, a difference in the quantities of food consumed was noted. The R9 ration with the lowest protein content (18.32 $\mathrm{g} / 100)$ was the most consumed $(119.49 \pm 52.11 \mathrm{~g} / \mathrm{d})$. This is in agreement with the conclusions of the INRA (1984) which notes that food intake can be influenced by the protein content of the diet. This institution mentions that in case of protein deficiency, the feed is over-consumed by some species to ensure a sufficient intake of amino acids.

The average live weights of the subjects obtained during the study are better than the live weights (615 and $656 \mathrm{~d}$ ) and (1028.2 $\pm 188.7 \mathrm{~g}$ ) obtained respectively by subjects fed by Bayala et al., (2016) in 63 days of breeding and Hien and Coulibaly (2017) in 12 weeks of breeding.

The live weights $1660.40 \pm 0.12 \mathrm{~g}, 1605.49 \pm 0.17 \mathrm{~g}$ and $1601.51 \pm 0.21 \mathrm{~g}$ obtained respectively from rations R6, R10 and R3 are similar to those from Ngueba (2006) (1660 to $1740 \mathrm{~g}$ ) and are also in accordance with the indications of the Agronomist's Manual (CIRAD-GRET, 2006) (1600 to 1900 g) for warm countries. However, these results are still lower than those of the studies conducted on broilers by CIEWE (2006) (2120,15 - 2280,42 g), NTIVUGURUZWA (2008) (2405.2 $2501.9 \mathrm{~g})$ and SANNI (2014) (2085.79 to $2126.06 \mathrm{~g})$.

This disparity in research results between different authors could be explained by the findings of Kondombo (2000) and Nougtara (2011) who noted that protein is the main limiting factor for bird growth and the genotype-protein level of the ration interaction on growth (Ngueba, 2006).

The average daily gains (ADGs) obtained in this study are much higher than the ADGs of $9 \mathrm{~g} / \mathrm{d}$ and $7.7 \mathrm{~g} / \mathrm{d}$ obtained in subjects fed respectively with the feed formulated by Hien and Coulibaly (2017) and Pousga et al., (2019). These data on the GMQ obtained are similar to the GMQ value (22 and $27 \mathrm{~g} / \mathrm{d}$ ) obtained by Bayala et al., (2016) However, the GMQ values obtained from the rations are much lower than the values of $58.57,64.28$ and $67.14 \mathrm{~g} / \mathrm{d}$ obtained by the subjects fed with the rations developed by Ngueba (2006). The difference in growth rate between the subjects fed the different rations could be explained by the genotype-protein level interaction of the ration on growth (Ngueba, 2006). Indeed, Okwuosa et al., (1990) noted in his work that there is a particularity of response of the genotype according to the protein content for feed intake and average daily gain. This difference would be related to the variable level of needs of each genotype in essential amino acids and the availability of these amino acids in the diet (Ngueba, 2006).

The average consumption index is the ratio between the total amount of feed consumed and the average live weight. It is an important economic criterion that allows us to assess the efficiency of the feeding process.

At the end of the present study, the ration consumption indices obtained are higher than the SANNI (2014) feed consumption index values (2.5 to 2.72 ). It was found that the consumption index increases with the number of days of rearing (Table VI). This observation is confirmed by other authors such as BETENE(2006) and ZONGO (2016)

The average cost (213.77 FCFA/Kg) of the formulas is lower than the cost (219.05 FCFA/Kg) of the feed formulated by Ouattara et al., (2015) and the price charged on the national market for poultry feed which varies between 240 and 300 FCFA/Kg (CPAVI ; Faso Grain, Kono Aliment ; Société de Fabrique d'Aliments pour Bétail) (Ouattara et al., 2015). This decrease can be explained by the rational use of raw materials in the formulation thanks to the design of experiments method.

\section{Conclusion}

This study showed that the formulation of poultry feed rations using the design of experiments method improved the zootechnical performance of local poultry « Poulet du Faso ». The live weight of the birds at the end of the study was higher in the birds receiving R6, R10 and R3. The average daily gain and feed conversion ratio were better, especially for birds fed the R6 ration. The costs of the rations are significantly lower than those of commercially available foods. Thus, the popularization of this formulation methodology using experimental designs could solve the problem of feed quality encountered by poultry farmers and thereby improve the profitability of their activity.

\section{Declarations}

\section{Acknowledgements}

This study was conducted at Expertise For Sens and Empowerment Farm.. The authors thank TAPSOBA Ambroise and the entire farm team for their contribution to this study. The ISP/IPICS/RABIOTECH project is grateful for the financial support.

\section{Statements}

\subsection{Funding}

This work was supported by ISP/IPICS/RABIOTECH project. Author Inoussa KY received research support from the Burkinabe state.

\subsection{Competing Interests}

The authors have no relevant financial or non-financial interests to disclose. 
The authors have no competing interests to declare that are relevant to the content of this article.

All authors certify that they have no affiliations with or involvement in any organization or entity with any financial interest or non-financial interest in the subject matter or materials discussed in this manuscript.

The authors have no financial or proprietary interests in any material discussed in this article.

Authors are responsible for correctness of the statements provided in the manuscript. See also Authorship Principles. The Editor-in-Chief reserves the right to reject submissions that do not meet the guidelines described in this section.

\subsection{Ethics approval}

No approval of research ethics committees was required to accomplish the goals of this study

\subsection{Consent to participate}

Not applicable' for that section

\subsection{Availability of data and material}

The datasets generated and/or analyzed in this study are not publicly available due to the data confidentiality of the Expertise For Sens and Empowerment farm where the study was conducted. But these data are available from the corresponding author upon reasonable request.

\subsection{Code availability}

Not applicable' for that section

\subsection{Author Contributions}

All authors contributed to the conception and design of the study. The preparation of the material, the collection and analysis of the data were carried out by Dr. Inoussa KY, and Dr. Charles PARKOUDA. The first draft of the manuscript was written by Dr. Inoussa KY and all authors commented on previous drafts of the manuscript. All authors read and approved the final manuscript.

\section{References}

Ayssiwede, S.B., Dieng, A., Houinato, M.R.B., Chrysostome, C.A.A.M., Issay, Hornick, J.L., Missohou, A., 2013. Elevage des poulets traditionels ou indigènes au Sénégal et en Afrique Subsahariene: État des lieux et contraintes. Ann. Med. Vet. 157, 103-119.

Bayala, B.O.B., Zoundi, J.S., Sawadogo, L., 2016. Effet de I' incorporation de graines d ' Hibiscus Sabdariffa ( Oseille de Guinée ) dans I ' alimentation sur quelques paramètres d ' ingestion et de croissance du poulet en aviculture traditionnelle améliorée au Burkina Faso . Agron. Africaine 27, $269-283$.

BETENE, A.D.C.L., 2006. Evaluation des performances zootechniques et économiques en période post reforme d'élevage de poulets de chair (souches cobbSOO et jupiter) dans la région de Dakar. UCADD, Dakar.

Brah, N., Houndonougbo, M., Issa, S., 2016. Etapes et méthodes de formulation d'aliment de volaille: Une synthèse bibliographique. Int. J. Biol. Chem. Sci. 9 , 2924. https://doi.org/10.4314/ijbcs.v9i6.31

CEDEAO/OCDE/CSAO, 2008. Élevage et marché régional au Sahel et en Afrique de I ' Ouest Potentialités et défis, 182 pages, Club du Sa. ed, Club du Sahel et de l'Afrique de l'Ouest/OCDE. Club du Sahel et de l'Afrique de I'Ouest/OCDE, Paris.

CIEWE, C.S., 2006. Evaluation de J'effet de la nature et du niveau de la matière grasse alimentaire sur la productivité du poulet de chair. UCADD , Dakar; Sénégal.

CIRAD-GRET, 2006. Mémento de l'Agronome, Edition du. ed. Ministère Français des Affaires Etrangères, Paris.

Cornell, J.A., 1941. Experiments with mixtures: designs, models, and the analysis of mixture data, 3rd ed. ed. Canada.

Crop, A., Society, S., Mbuya, K., Pongi, G.K., Mundondo, A.E., Anageanatiga, O.E., 2014. Effet du mais a forte teneur en proteine sur l'élevage des poulets de chair dans la province du bas-congo et l'impact sur sa production en république démocratique du congo. African Crop Sci. J. 22, 969-977.

FAO, 2019. Table de composition des aliments FAO/INFOODS pour l'Afrique de l'Ouest (2019). Genève.

FAO, 2018. Le développement durable de l'élevage africain: approche «Une seule santé» au Burkina Faso. Rome,.

Goupy, J., 2006. Les plan d'expérience. Rev. Modul. 34, 74-116.

Hien, O.C., Coulibaly, B.D.Y., 2017. Effets d' une ration à base de la variété de maïs «Espoir» sur la productivité des poulettes Effects of " Espoir " variety of corn on chicken productivity $11,806-816$. 
Hofman A, 2000. Amélioration de l'aviculture traditionnelle aux îles Comores: Impact de la semi-claustration et de la complémentation par une provende locale sur la productivité de la volaille locale.

INRA, 1984. L'alimentation des animaux monogastriques: porc, lapin, volailles.-, INRA. ed. Paris.

Insd, 2008. RECENSEMENT GENERAL DE LA POPULATION ET DE L'HABITATION, Population (English Edition). MINISTERE DE L'ECONOMIE ET DES FINANCES, Ouagadougou.

INSD, 2014. Tableau de bord 2013 de la région du Centre-Sud. Ouagadougou.

Kondombo RS, 2005. BURKINA FASO Revue du secteur avicole. Ouagadougou.

MASA, 2013. Référentiel technico économique pour la mise en place d'une exploitation de poulets de race locale. Ouagadougou.

MRA, M. des R.A., 2010. Politique Nationale de Développement Durable de l'Elevage au Burkina Faso.

NDiagne, N., 1996. Etude de la qualité nutritionnelle des aliments de volaille vendus au Sénégal et de l'effet de leur supplémentation en lysine, en méthionone et en lipides sur les performances zootechniques du pouletde chair.

Ngom, S., 2004. Ebauche d'un référentiel sur la composition chimique et valeur nutritive des matières premières utilisables en alimentation des volailles au Sénégal 158.

Ngueba, M.L., 2006. L'influence de la substitution du maïs par le niébé sur les performances de croissance du poulet de chair en milieu tropical sec. UNIVERSITE CHEIKH ANTA DIOP DE DAKAR.

NTIVUGURUZWA, J.B., 2008. Effets de l'infuse des racines entières de nal/clea lalifolia sur les perfonnances de croissance du poulet de chair. UCADD, Dakar; Sénégal.

OKWUOSA, B.., AGBAKOBA, A.M., BNOKWUOSA., ANUGWA, AWAEGBUTE, 1990. Performance of different genotype of broiler chicks fed varying protein levels in their starter and finisher diets. Bull. Anim. Hilt Prod 38, 69-76.

Oladokun, V.., Johnson, A., 2012. Feed formulation problem in Nigerian poultry farms: a mathematical programming approach. Am. J. Sci. Ind. Res. 3, 14-20. https://doi.org/10.5251/ajsir.2012.3.1.14.20

Ouattara, S., Bougouma-Yameogo, V., Nianogo, A., Al Bachir, A., 2015. Effets des graines torréfiées de Vigna unguiculata (niébé) comme source de protéines, dans l'alimentation des poules locales en ponte au Burkina Faso, sur leurs performances zootechniques et la rentabilité économique des régimes. Int. J. Biol. Chem. Sci. 8, 1991-8631. https://doi.org/10.4314/ijbcs.v8i5.4

Pousga, S., Boly, H., Linderberg, J., Ogle, B., 2005. Scavenging pullets in Burkina Faso: Effects of season, location and breed on feed and nutrient intake. Trop. Anim. Heal. Prod 37, 623-634.

Pousga, S., Sankara, F., Coulibaly, K., Nacoulma, J.P., Ouedraogo, S., Kenis, M., Chrysostome, C., Ouedraogo, G.A., 2019. Effets du remplacement de La farine de poisson par les termites (Macrotermes Sp.) sur l'evolution ponderale Et les caracteristiques de carcasse de la volaille locale au Burkina Faso. African J. Food, Agric. Nutr. Dev. 19, 14354-14371. https://doi.org/10.18697/AJFAND.85.17430

SANNI, J.Y., 2014. Effets d'une litière à base d’attapulgite calcinée, sur les performances de croissance du poulet de chair. UCADD, Dakar, Sénégal.

Saxena, P., 2012. Comparison of Linear and Nonlinear Programming Techniques for Animal Diet. J. Appl. Math. 1, $106-108$.

https://doi.org/10.5923/j.am.20110102.17

Scheffé, H., 1958. Experiments with Mixtures. J. R. Stat. Soc. Ser. B 20, 344-360. https://doi.org/doi:10.1111/j.2517-6161.1958.tb00299.x

Sonaiya, E.., Swan, S.E.., 2004. Production en aviculture familiale. Manuel FAO de Production et Santé Animales, FAO, Rome. ed.

ZONGO, R., 2016. Etude comparée de la rentabilité économique des poulets de chair alimentés avec des rations comprenant des ingrédients industriels. UPB.

\section{Tables}

Table I: Lower and upper limits of factors (raw materials) 


\begin{tabular}{lll} 
Raw materials & Lower Limit (g/100g) & $\begin{array}{l}\text { Upper limit } \\
(\mathrm{g} / 100 \mathrm{~g})\end{array}$ \\
\hline Crushed corn kernel & 40 & 44.75 \\
\hline Oilcake Crushed cotton & 5 & 9.75 \\
\hline Oilcake Crushed soybeans & 15 & 19.79 \\
\hline Wheat bran & 5 & 9.75 \\
\hline Rice bran & 10 & 14.75 \\
\hline Fish meal & 10 & 14.75 \\
\hline Oyster shell & 2.5 & 7.25 \\
\hline Dicalcium phosphate & 2.5 & 7.25 \\
\hline salt & 0.25 & 5 \\
\hline Mineral-Vitamin-Azote Concentrate (CMVA) & 5 & 9.75
\end{tabular}

Table II : Composition and nutritional value of experimental rations

\begin{tabular}{|c|c|c|c|c|c|c|c|c|c|c|}
\hline \multirow[t]{2}{*}{ Ingredients } & \multicolumn{10}{|c|}{ Experimental rations } \\
\hline & R1 & R2 & R3 & R4 & R5 & R6 & R7 & R8 & R9 & R10 \\
\hline Maize (\%) & 44.75 & 40 & 40 & 40 & 40 & 40 & 40 & 40 & 40 & 40 \\
\hline Cotton cake (\%) & 5 & 9.75 & 5 & 5 & 5 & 5 & 5 & 5 & 5 & 5 \\
\hline Soybean cake (\%) & 15 & 15 & 19.75 & 15 & 15 & 15 & 15 & 15 & 15 & 15 \\
\hline Wheat bran (\%) & 5 & 5 & 5 & 9.75 & 5 & 5 & 5 & 5 & 5 & 5 \\
\hline Rice bran (\%) & 10 & 10 & 10 & 10 & 14.75 & 10 & 10 & 10 & 10 & 10 \\
\hline Fish meal (\%) & 10 & 10 & 10 & 10 & 10 & 14.75 & 10 & 10 & 10 & 10 \\
\hline Oyster shell (\%) & 2.5 & 2.5 & 2.5 & 2.5 & 2.5 & 2.5 & 7.25 & 2.5 & 2.5 & 2.5 \\
\hline Dicalcium phosphate (\%) & 2.5 & 2.5 & 2.5 & 2.5 & 2.5 & 2.5 & 2.5 & 7.25 & 2.5 & 2.5 \\
\hline Salt (\%) & 0.25 & 0.25 & 0.25 & 0.25 & 0.25 & 0.25 & 0.25 & 0.25 & 5 & 0.25 \\
\hline CMVA (\%) & 5 & 5 & 5 & 5 & 5 & 5 & 5 & 5 & 5 & 9.75 \\
\hline Cost-formula (FCFA) & 207.15 & 206.91 & 215.23 & 205.63 & 203.5 & 215.23 & 205.73 & 238.98 & 205.25 & 234.23 \\
\hline \multicolumn{11}{|c|}{ Chemical composition of experimental rations } \\
\hline Metabolisable energy (kcal/kg) & 2837.90 & 2753.15 & 2757.88 & 2742.85 & 2849.06 & 2770.00 & 2660.62 & 2655.82 & 2657.24 & 2644.24 \\
\hline Crude protein (\%) & 18.82 & 20.28 & 20.47 & 19.10 & 19.04 & 20.28 & 18.41 & 18.37 & 18.32 & 18.36 \\
\hline Fats (\%) & 5.21 & 5.09 & 5.05 & 5.13 & 5.70 & 5.38 & 4.98 & 4.97 & 4.97 & 4.86 \\
\hline Carbohydrates (\%) & 40.40 & 37.09 & 3712 & 37.94 & 39.35 & 36.88 & 36.91 & 36.85 & 36.93 & 36.81 \\
\hline Crude cellulose (\%) & 7.58 & 7.79 & 7.37 & 7.77 & 7.27 & 7.11 & 7.12 & 7.14 & 7.06 & 7.04 \\
\hline Available phosphorus (\%) & 1.26 & 1.26 & 1.25 & 1.20 & 1.28 & 1.42 & 1,22 & 2.11 & 1.19 & 1.17 \\
\hline Calcium (\%) & 2.21 & 2.22 & 2.23 & 2.18 & 2.23 & 2.49 & 3.86 & 3.40 & 2.15 & 1.67 \\
\hline Lysine (\%) & 0.87 & 0.88 & 0.94 & 0.87 & 0.89 & 0.95 & 0.88 & 0.81 & 0.78 & 0.78 \\
\hline Methionine (\%) & 0.43 & 0.44 & 0.43 & 0.38 & 0.41 & 0.48 & 0.36 & 0.43 & 0.38 & 0.36 \\
\hline Threonine (\%) & 0.75 & 0.84 & 0.81 & 0.76 & 0.77 & 0.83 & 0.75 & 0.72 & 0.72 & 0.68 \\
\hline
\end{tabular}

$\mathrm{R}=$ Ration

Table III : Average daily food consumption of subjects (in grams) 


\begin{tabular}{|c|c|c|c|c|c|c|c|c|c|}
\hline $\begin{array}{l}\text { Age } \\
\text { of } \\
\text { subjects } \\
\text { (in } \\
\text { weeks) }\end{array}$ & R1 & R2 & R3 & R4 & R5 & R6 & R7 & R8 & R9 \\
\hline W1 & $48.69 \pm 0.16^{b}$ & $44.43 \pm 0.22^{f}$ & $36.73 \pm 0.04^{j}$ & $49.13 \pm 0.13^{a}$ & $45.09 \pm 0.07^{e}$ & $47.39 \pm 0.03^{c}$ & $42.48 \pm 0.12^{h}$ & $40.07 \pm 0.03^{i}$ & $47.10 \pm 0$. \\
\hline w2 & $59.45 \pm 0.45^{d}$ & $55.68 \pm 0.57^{j}$ & $60.42 \pm 0.43^{\mathrm{C}}$ & $61.78 \pm 0.57^{b}$ & $59.62 \pm 0.10^{f}$ & $55.74 \pm 0.57^{i}$ & $59.19 \pm 0.45^{\mathrm{e}}$ & $56.38 \pm 0.32^{h}$ & $62.53 \pm 0$. \\
\hline W3 & $71.17 \pm 0.37^{d}$ & $67.16 \pm 0.25^{\mathrm{h}}$ & $72.51 \pm 0.02^{c}$ & $73.38 \pm 0.12^{b}$ & $70.80 \pm 0.37^{e}$ & $67.34 \pm 0.12^{f}$ & $59.39 \pm 0.25^{j}$ & $62.16 \pm 0.25^{i}$ & $74.83 \pm 0$. \\
\hline W4 & $97.95 \pm 0.05^{d}$ & $94.19 \pm 0.07^{j}$ & $98.94 \pm 0.05^{c}$ & $100.16 \pm 0.05^{f}$ & $97.58 \pm 0.05^{f}$ & $94.12 \pm 0.05^{i}$ & $97.82 \pm 0.07^{e}$ & $94.76 \pm 0.05^{\mathrm{h}}$ & $101.612 \pm$ \\
\hline W5 & $114.32 \pm 0.42^{\mathrm{d}}$ & $110.31 \pm 0.30^{\mathrm{j}}$ & $115.02 \pm 0.14^{c}$ & $116.72 \pm 0.24^{b}$ & $113.95 \pm 0.17^{f}$ & $110.49 \pm 0.42^{i}$ & $113.94 \pm 0.30^{\mathrm{e}}$ & $111.13 \pm 0.17^{\mathrm{h}}$ & $117.98 \pm C$ \\
\hline W6 & $138.77 \pm 0.47^{d}$ & $134.76 \pm 0.35^{j}$ & $139.79 \pm 0.50^{c}$ & $141.34 \pm 0.11^{\mathrm{b}}$ & $138.27 \pm 0.35^{f}$ & $134.94 \pm 0.47^{i}$ & $138.39 \pm 0.35^{\mathrm{e}}$ & $135.46 \pm 0.35^{h}$ & $142.30 \pm C$ \\
\hline W7 & $152.6 \pm 0.30^{d}$ & $148.83 \pm 0.42^{\mathrm{j}}$ & $153.58 \pm 0.30^{c}$ & $154.81 \pm 0.30^{\mathrm{b}}$ & $152.35 \pm 0.17^{f}$ & $148.61 \pm 0.45^{i}$ & $152.34 \pm 0.30^{\mathrm{e}}$ & $149.71 \pm 0.25^{\mathrm{h}}$ & $156.38 \mathrm{v} 0$ \\
\hline w8 & $175.57 \pm 0.57^{d}$ & $171.56 \pm 0.45^{j}$ & $176.18 \pm 0.05^{c}$ & $177.78 \pm 0.57^{b}$ & $175.07 \pm 0.45^{f}$ & $171.62 \pm 0.45^{i}$ & $175.31 \pm 0.57^{e}$ & $172.26 \pm 0.45^{\mathrm{h}}$ & $179.23 \pm C$ \\
\hline W9 & $190.57 \pm 0.30^{\mathrm{e}}$ & $183.72 \pm 0.30^{\mathrm{j}}$ & $192.21 \pm 0.56^{d}$ & $193.87 \pm 0.30^{\mathrm{b}}$ & $189.67 \pm 0.02^{f}$ & $186.57 \pm 0.30^{\mathrm{h}}$ & $186.77 \pm 0.77^{a}$ & $190.78 \pm 0.77^{i}$ & $193.45 \pm C$ \\
\hline Average & 116.57 & 112.30 & 116.16 & 118.781 & 115.828 & 112.986 & 113.962 & 112.529 & 119.49 \\
\hline Ecartyp & 51.27 & 50.79 & 53.58 & 51.77 & 51.63 & 50.78 & 53.01 & 53.45 & 52.11 \\
\hline
\end{tabular}

Values reported in the same row with different superscript letters are significantly different at the $\mathrm{P}<0.05$ threshold.

$\mathrm{R}=$ Ration

$W=$ Week

Table IV : Average live weight of subjects

\begin{tabular}{|c|c|c|c|c|c|c|c|c|}
\hline $\begin{array}{l}\text { Age } \\
\text { of } \\
\text { subjects } \\
\text { (in } \\
\text { weeks) }\end{array}$ & $\mathrm{R} 1$ & $\mathrm{R} 2$ & R3 & R4 & R5 & R6 & R7 & $\mathrm{R \varepsilon}$ \\
\hline wo & 127.55 & 134.13 & 137.75 & 158.01 & 128.43 & 124.40 & 144.21 & 15 \\
\hline W1 & $301.88 \pm 0.20 b$ & $304.21 \pm 0.20 b$ & $321.28 \pm 0.24 a b$ & $224.57 \pm 0.15 c$ & $295.68 \pm 0.07 b$ & $380.65 \pm 0.09 a$ & $298.61 \pm 0.08 b$ & 31 \\
\hline W2 & $372.65 \pm 0.24 b c$ & $363.16 \pm 0.16 b c$ & $386.90 \pm 0.23 b c$ & $474.79 \pm 0.12 a$ & $346.22 \pm 0.09 b c$ & $426.28 \pm 0.10 a b$ & $313.61 \pm 0.08 c$ & 34 \\
\hline W3 & $573.74 \pm 0.21 a$ & $579.62 \pm 0.15 a$ & $562.77 \pm 0.18 a$ & $635.78 \pm 0.11 a$ & $584.67 \pm 0.09 a$ & $644.49 \pm 0.12 a$ & $415.21 \pm 0.07 b$ & 43 \\
\hline W4 & $740.44 \pm 0.30 \mathrm{bcd}$ & $758.97 \pm 0.17 \mathrm{bcd}$ & $793.78 \pm 0.20 \mathrm{ab}$ & $814.72 \pm 0.11 a b$ & $740.31 \pm 0.06 \mathrm{bcd}$ & $907.32 \pm 0.10 a$ & $625.64 \pm 0.09 \mathrm{~cd}$ & 61 \\
\hline W5 & $802.96 \pm 0.27 \mathrm{bcde}$ & $883.53 \pm 0.19 a b$ & $904.91 \pm 0.21 \mathrm{ab}$ & $837.94 \pm 0.11 \mathrm{bcde}$ & $861.01 \pm 0.06 \mathrm{bcd}$ & $1031.70 \pm 0.13 a$ & $724.53 \pm 0.08 \mathrm{de}$ & 73 \\
\hline W6 & $914.70 \pm 0.24 \mathrm{cde}$ & $1008.01 \pm 0.20 \mathrm{bcd}$ & $1043.63 \pm 0.18 a b c$ & $909.26 \pm 0.13 \mathrm{cde}$ & $985.66 \pm 0.012 \mathrm{bcd}$ & $1195.04 \pm 0.07 a$ & $836.91 \pm 0.09 \mathrm{de}$ & 86 \\
\hline W7 & $1101.10 \pm 0.15 b c$ & $1161.27 \pm 0.17 a b c$ & $1267.74 \pm 0.28 a b$ & $1094.92 \pm 0.14 b c$ & $1160.61 \pm 0.05 a b c$ & $1335.46 \pm 0.08 a$ & $1003.64 \pm 0.08 c$ & $1 \mathrm{C}$ \\
\hline W8 & $1154.81 \pm 0.25 \mathrm{c}$ & $1256.18 \pm 0.15 b c$ & $1381.33 \pm 0.15 a b$ & $1180.58 \pm 0.10 b c$ & $1211.25 \pm 0.07 b c$ & $1486.33 \pm 0.14 a$ & $1056.83 \pm 0.08 c$ & 11 \\
\hline W9 & $1263.33 \pm 0.26 b c d$ & $1445.40 \pm 0.14 a b$ & $1601.51 \pm 0.24 a$ & $1294.67 \pm 0.13 \mathrm{bcd}$ & $1313.72 \pm 0.08 \mathrm{bc}$ & $1660.40 \pm 0.12 \mathrm{a}$ & $1089.53 \pm 0.07 d$ & 12 \\
\hline
\end{tabular}

Values reported in the same row with the same superscript letters are not significantly different at the $\mathrm{P}<0.05$ threshold.

$\mathrm{R}=$ Ration

$W=$ Week

Table V : Average daily gain 


\begin{tabular}{|c|c|c|c|c|c|c|c|c|c|c|}
\hline $\begin{array}{l}\text { Age } \\
\text { of subjects } \\
\text { (in weeks) }\end{array}$ & R1 & R2 & R3 & R4 & R5 & R6 & R7 & R8 & R9 & R10 \\
\hline W1 & 43.13 & 43.46 & 45.9 & 32.52 & 42.24 & 54.38 & 42.66 & 44.44 & 44.59 & 25.26 \\
\hline W2 & 26.62 & 25.94 & 27.64 & 33.91 & 24.73 & 30.45 & 22.4 & 24.49 & 26.1 & 23.9 \\
\hline W3 & 27.32 & $2 ., 6$ & 26.8 & 30.28 & 27.84 & 30.69 & 19.77 & 20.87 & 20.33 & 27.65 \\
\hline W4 & 26.44 & 27.11 & 28.35 & 28.6 & 26.44 & 32.4 & 22.34 & 22.1 & 21.95 & 26.24 \\
\hline W5 & 22.94 & 25.24 & 25.85 & 23.94 & 24.6 & 29.48 & 20.7 & 20.96 & 19.75 & 25.08 \\
\hline W6 & 21.78 & 24 & 24.85 & 21.65 & 23.47 & 28.45 & 19.93 & 20.53 & 19.08 & 26.06 \\
\hline W7 & 22.47 & 23.7 & 25.87 & 22.35 & 23.69 & 27.25 & 20.48 & 21.51 & 20.37 & 27.07 \\
\hline w8 & 20.62 & 22.43 & 24.67 & 21.08 & 21.63 & 26.54 & 18.87 & 20.23 & 18.86 & 26.23 \\
\hline W9 & 21.06 & 24.09 & 26.69 & 21.58 & 21.9 & 27.67 & 18.16 & 20.21 & 19.5 & 26.76 \\
\hline Average & 25.81 & 27.07 & 28.52 & 26.21 & 26.28 & 31.92 & 22.81 & 23.92 & 23.39 & 26.03 \\
\hline Ecart-type & 6.97 & 6.37 & 6.63 & 5.12 & 6.30 & 8.63 & 7.57 & 7.81 & 8.25 & 1.14 \\
\hline
\end{tabular}

$\mathrm{R}=$ Ration

$\mathrm{W}=$ Week

Table VI : Consumption index

\begin{tabular}{|c|c|c|c|c|c|c|c|c|c|c|}
\hline $\begin{array}{l}\text { Age } \\
\text { of subjects } \\
\text { (in weeks) }\end{array}$ & R1 & $\mathrm{R} 2$ & R3 & R4 & R5 & R6 & R7 & R8 & R9 & R10 \\
\hline W1 & 1.71 & 1.58 & 1.21 & 1.58 & 1.67 & 1.34 & 1.55 & 1.38 & 1.61 & 1.63 \\
\hline W2 & 2.32 & 2.06 & 2.11 & 2.22 & 2.29 & 1.67 & 2.52 & 2.20 & 2.47 & 2.30 \\
\hline W3 & 2.35 & 2.14 & 2.32 & 2.56 & 2.28 & 1.89 & 2.59 & 2.61 & 3.24 & 2.43 \\
\hline W4 & 3.47 & 3.13 & 3.12 & 3.58 & 3.38 & 2.70 & 3.94 & 3.82 & 4.26 & 3.48 \\
\hline W5 & 4.52 & 4.01 & 4.05 & 4.64 & 4.30 & 3.52 & 5.05 & 4.91 & 5.21 & 4.65 \\
\hline W6 & 5.82 & 5.18 & 5.15 & 5.75 & 5.50 & 4.47 & 6.41 & 5.94 & 6.51 & 5.52 \\
\hline W7 & 6.22 & 5.87 & 5.59 & 6.27 & 6.09 & 5.21 & 6.98 & 6.40 & 6.97 & 5.82 \\
\hline W8 & 7.77 & 7.20 & 6.89 & 7.68 & 7.26 & 6.20 & 8.58 & 7.89 & 8.61 & 7.07 \\
\hline W9 & 8.23 & 7.65 & 7.47 & 8.52 & 8.27 & 6.20 & 9.27 & 9.07 & 9.19 & 6.90 \\
\hline Average & 4.71 & 4.31 & 4.21 & 4.75 & 4.56 & 3.69 & 5.21 & 4.91 & 5.34 & 4.42 \\
\hline Ecartyp & 2.43 & 2.28 & 2.20 & 2.47 & 2.36 & 1.92 & 2.77 & 2.64 & 2.68 & 2.05 \\
\hline
\end{tabular}

$\mathrm{R}=$ Ration

$\mathrm{W}=$ Week

\section{Figures}




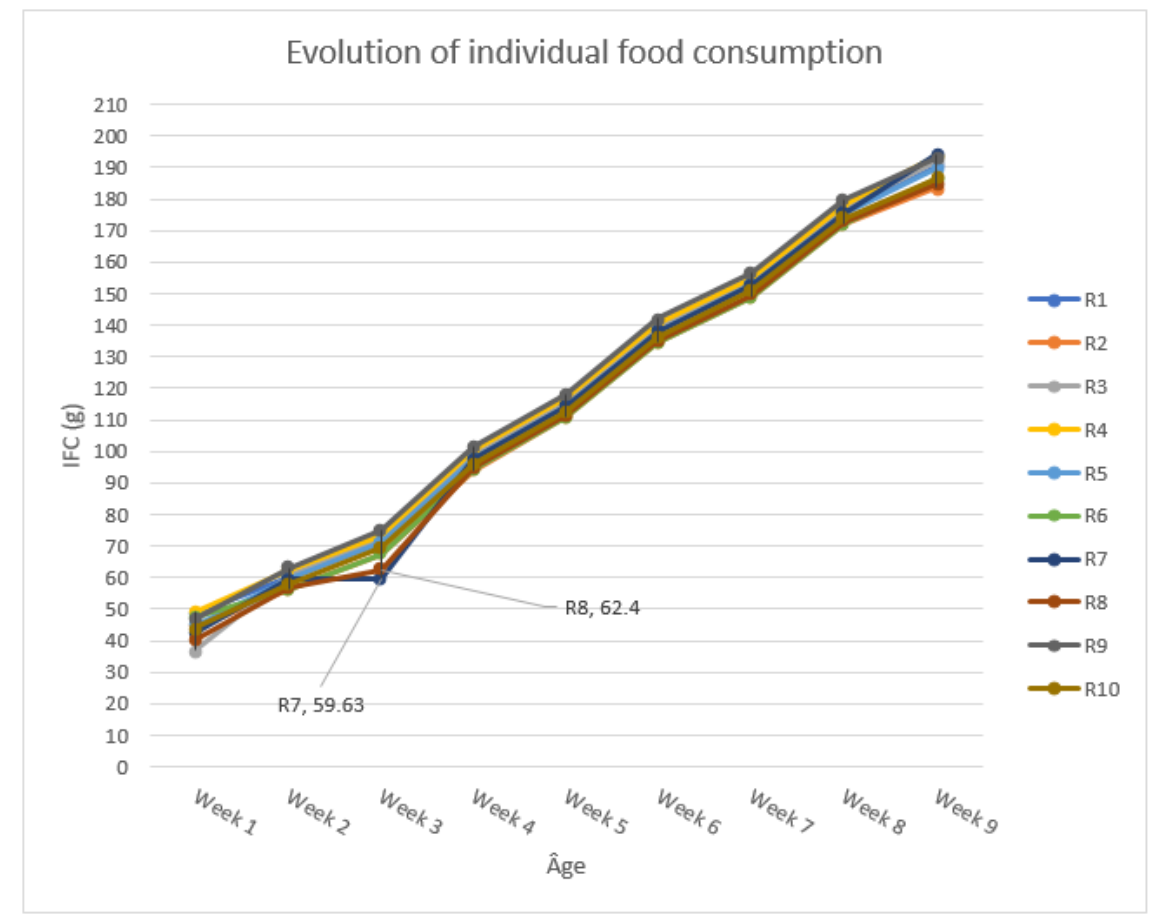

IFC = Individual Food Fonsumption

$\mathrm{R}=$ Ration

Figure 1

Evolution of individual food consumption/ day (g)

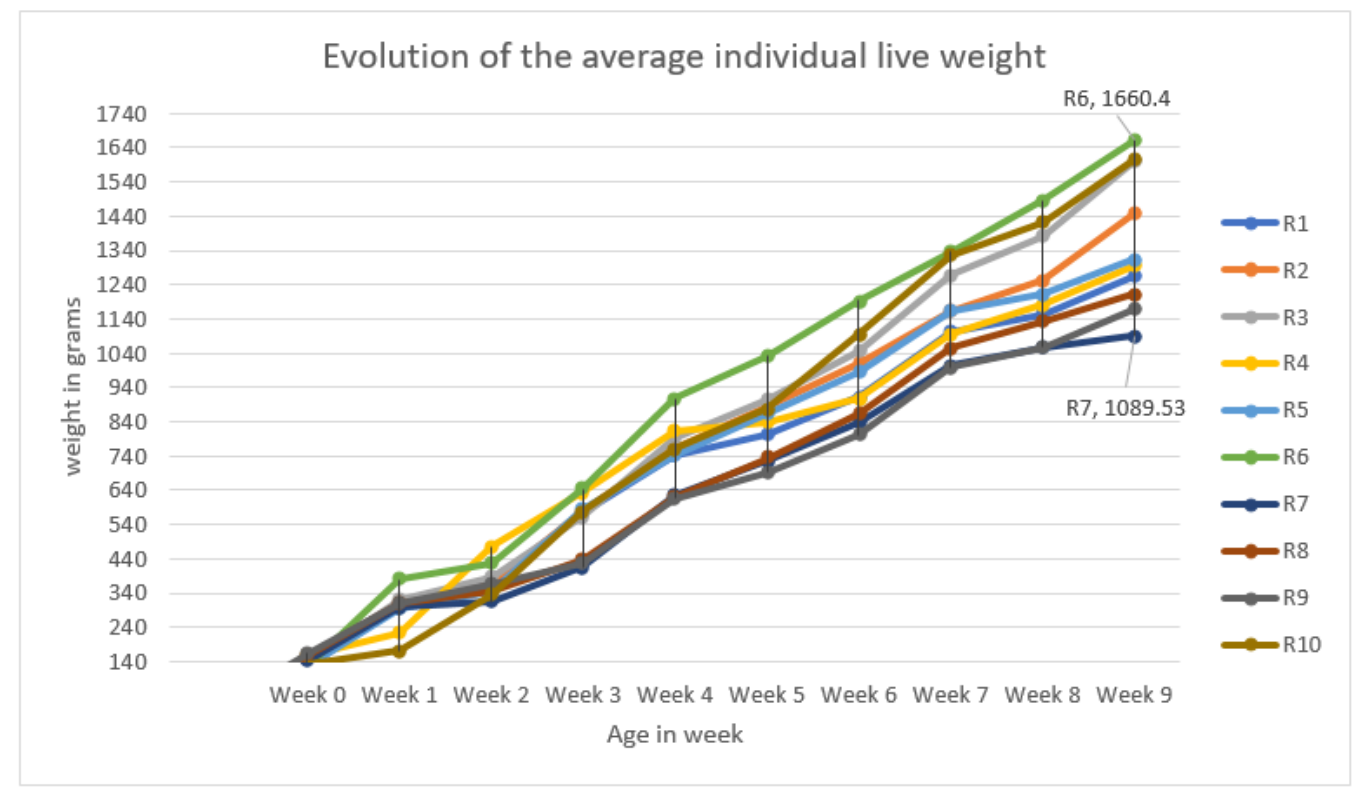

$\mathrm{R}=$ Ration

\section{Figure 2}

Evolution des poids vifs 


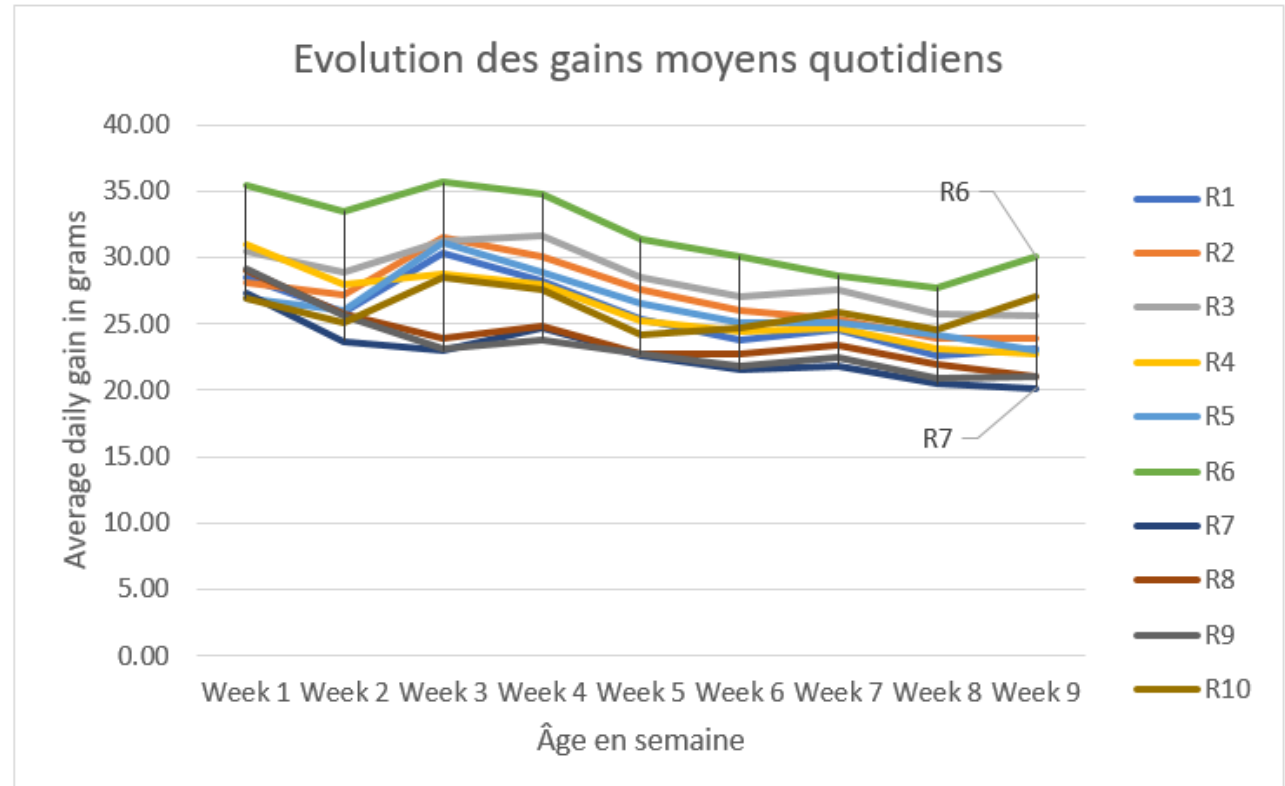

$\mathrm{R}=$ Ration

Figure 3

Evolution des gains moyens quotidiens

\section{Supplementary Files}

This is a list of supplementary files associated with this preprint. Click to download.

- Statement.docx 